\title{
LEGAL REGULATION OF THE APPLICATION OF ECONOMIC MECHANISMS FOR ENSURING THE RATIONAL USE OF NATURAL RESOURCES: THE EXPERIENCE OF FOREIGN COUNTRIES
}

\author{
Yuliia Leheza', Olena Surilova ${ }^{2}$
}

\begin{abstract}
The purpose of the study is to determine the most optimal ways to solve the problems of financing the implementation of environmental protection measures formulated based on the positive experience of foreign countries in the field of ensuring the rational use of natural resources. Methodology. The method of comparative legal research was used to analyse foreign experience in the application of economic mechanisms for ensuring the rational use of natural resources, and the methods of modelling, analysis, and synthesis allowed determining the directions of increasing the efficiency of economic incentive use in Ukraine. Research results. Based on the studied experience of legal regulation of the application of economic mechanisms for ensuring the rational use of natural resources in the countries of the European Union, the United States of America, Great Britain, Canada, and other foreign countries, it was concluded on the expediency of its implementation in Ukraine. The author determined the appropriateness of the introduction of tax privileges of economic activity of entities that promote the use of advanced technologies, which contribute to reducing the negative impact on the environment. The expediency of application in Ukraine of an extensive system of taxation of activities associated with the use of natural resources by means of activating the introduction of direct taxes paid directly by natural users is substantiated. The practicability of inclusion of payments for obtaining appropriate special permits (licenses), which are granted not only for the use of natural resources but also for the activities related to environmental pollution, in the system of economic mechanisms for ensuring the rational use of natural resources is substantiated. The practical importance of the study. The expediency of introducing in Ukraine the approach of financial substantiation of national and regional programs in the sphere of natural resources utilization, which are realized at the expense of state and local budgets and successfully applied in foreign countries, is proved. The originality of the research. The results and conclusions of the research can be used in the process of improving the legal regulation of the application of economic mechanisms for ensuring the rational use of natural resources.
\end{abstract}

Key words: administrative act, use of natural resources, permit, environmental tax, economic mechanism, license.

JEL Classification: E63, H21, K32, K34, Q20

\section{Introduction}

In the conditions of the rapid development of energy consumption, increasing technogenic and anthropogenic pressure on the environment, the issue of solving environmental problems ceases to be a domestic problem and requires the effective application of international and intergovernmental levers of influence. Implementation of environmental protection measures is impossible without proper funding. The study of the experience of public management in the sphere of the use of natural resources in foreign countries will allow optimizing the modern national environmental protection system.

Corresponding author:

${ }^{1}$ Institute of Human and Social Sciences,

National Technical University "Dnipro Polytechnic”, Ukraine.

E-mail: legezajul@gmail.com

${ }^{2}$ National University “Odesa Law Academy”, Ukraine.

E-mail: elenasurilova@ukr.net
The introduction of the environmental tax in Ukraine has become an unconditional achievement of the tax reform, but its effectiveness, unfortunately, has not been confirmed by time. Such a conclusion is based on the state of the environment in Ukraine. A significant part of the territory of Ukraine is approaching the inevitable ecological catastrophe, associated with the lack of an efficient system of accumulation of financial resources for the formation of natural guard funds, with the need to introduce a system of formation of secondary mineral raw material base capable of solving not only environmental but also energy problems. The search for the most optimal ways to solve problems of financing 
the implementation of environmental protection measures is possible through the introduction of foreign experience in the field of study, which determined the purpose of this research.

The formation of comparative law science is becoming more and more relevant in the context of the integration of modern legal systems, the convergence of law systems. The development of the science of comparative law was initiated in the writings of such scholars as M. M. Marchenko, L. A. Luts, P. M. Rabinovych, O. V. Kresin, M. A. Damirli, Yu. O. Tykhomyrov, and others. Determination of foreign experience of public administration in certain spheres of public life becomes particularly relevant in the context of the intensification of European integration processes and the need for the introduction of international standards of legal regulation. The improvement of the public administration system in the sphere of use of natural resources is a part of the EU Association Agreement signed by Ukraine with the European Union in 2014, the implementation of which is scheduled for 2022. Therefore, issues of studying the systems of economic mechanisms for ensuring the rational use of natural resources in foreign countries, including the countries of the European Union, which predetermine the purpose of writing this article, become especially relevant.

\section{Permit-licensing proceedings as a means of ensuring the economical use of natural resources in foreign countries}

Modern states seek to consolidate the regulation of the protection of the rights of citizens to a safe environment at the constitutional and legal level, and thus, the implementation of the ecological function of the state is declared as a direction of the state's activities in the environmental protection, restoration, and reproduction, rational use of natural resources owned by state, territorial communities, legal entities, and individuals, provision of environmental safety, security and protection of environmental rights of individuals and legal entities. Conducting this study, we can say that the specific principles governing the use of certain types of resources can be distinguished in the legislation of some industrialized countries.

Licensing the use of natural resources is a widespread form of public administration in such foreign countries as Great Britain, France, Germany, etc. In Great Britain, all significant water intakes from surface and groundwater are controlled by the licensing system through the identification in the licenses of the amount of water that can be taken from the water source. Most applications for licenses require a comprehensive assessment of the availability of resources and the possible impact on the environment. In order to protect the environment, a large number of licenses issued for water intake from water sources considerably limit water intake during low water years or allow special water use only in winter, when the volume of natural water resources increases (Mandzyk).

The opposite of the licensing system is the system for the sale and purchase of rights to use water resources (USA, Canada, Mexico). For example, the system of payments for the use of water resources in the countries of Western Europe consists of two main types of payments: 1) payments for water resources intended for redistribution (extraction) of rent from the water user that appears in the process of exploitation of water resources (they are determined based on the value of rental income and are oriented towards that part which should be withdrawn from the water user); 2) payments to maintain the existing water management system. They are a tool for collecting funds necessary to cover administrative costs for controlling the use of water resources and certain infrastructure costs (any licensing fees, etc.). Additional payments are withdrawn for services related to the assessment of water resources (laboratory analysis, registration and certification of documents, etc.). These payments come to a special fund designed to improve the quality of the relevant services (Khvesyk, Holian, 2007).

\section{Taxation of activities related to the use of natural resources in foreign countries}

Formation of environmental funds is carried out not only at the expense of revenues from the use of natural resources, obtaining special permits or licenses for their use, or for receiving other types of administrative (public) services in the field of natural resource use, but also through the introduction of taxation of activities, resulting in the environmental deterioration. In particular, in the Federal Republic of Germany, the taxation of lubricating oils, crude oil, and petroleum products is additionally introduced (Mandzyk). Under the same principle, the system of environmental taxes and fees is built in the French Republic, Finland, and Italy. Similarly, fuel tax is the source of special funds for environmental protection measures in the Netherlands. Such a tax covers $50 \%$ of expenses of the Ministry of Ecology, including expenses for prevention and compensation of losses, subsidization of implementation of advanced technologies for cleaning and processing, as well as financing of chemical waste disposal (Malikova, 2001).

Taxation of activities related to the use of natural resources in foreign countries is carried out through the issuance of such types of compulsory payments as royalty, sovereign tax, special taxes on profits of mining companies, differentiated rent payments, land tax, payment for the right to subsoil use, deductions for protection and restoration of subsoil, excise, emission fee, sales tax, export tax, and others. Herewith, the advantage is given to taxation in a direct way or direct taxes. In particular, renters are, as a rule, users of natural resources. The most important direct taxes on natural 
resources include the following: rent, tax on access to natural resources, taxes on mining and exploration, as well as payment for the right to use natural resources, calculated per unit of the leased territory. The rent is set at the nominal level in the first years of exploitation of the natural resource but gradually increases to stimulate the tenant to develop production. Royalties - a payment to the state for the right to use an exhaustive natural resource. It is calculated based on the gross income of the producer, but not net profit (Martynenko).

Also, among the means of public administration in the field of natural resources utilization, which have become widespread in the countries of Western Europe, there is the application of preferential taxation of investment activity aimed at reducing the negative impact on the natural environment. In the Netherlands, in particular, tax incentives are applied in the amount of $10-15 \%$ of the total amount of environmental tax if the enterprise implements investments for environmental protection measures (Martynenko). Similarly, in Spain, tax incentives have been introduced up to $30 \%$ of environmental investment activity (Martynenko).

\section{Introduction of innovative environmental technologies for energy saving as a basis for applying economic incentives to business entities}

Numerous scientific studies in the field of ecology, economics, and economics of nature use have repeatedly proved that the use of natural resources as sources of energy is enough for no more than 50-60 years. Accordingly, the use of the secondary mineral raw material base, including technogenic waste, other renewable energy sources, will allow solving a significant number of global energy supply problems in Europe, the USA, and Canada.

In accordance with the Joint Declaration of the member states of the European Union, priority issue to be considered by the European Commission is the consideration of legislative initiatives related to the Energy Union, in particular those that are a part of the Clean Energy for all Europeans Program (European Commission, 2016).

One of the measures that have proved its effectiveness in the countries of Western Europe and the USA is the environmental labelling of hazardous products, which is carried out based on environmental certification of the enterprise and environmental licensing of economic activity as a means of public administration in the field of ensuring environmental safety requirements (EnvironmentalstatisticsinEurope,2010).Environmental labelling is an advertising tool that stimulates the sale of environmentally friendly goods, which makes them more competitive compared to unmarked, increases demand for them. This enables manufacturers to raise the price of these types of goods, compensating for the increased costs of their environmentalization. Eco-labelling significantly influences the amount of import duties by reducing them.

The European Commission constantly monitors the environment of the European Union member states. In particular, in June 2017, the Commission approved a reasoned opinion addressed to the Government of the Republic of Poland on the need to take measures to reduce the emission of gasoline vapour into the air, in accordance with the requirements of Commission Directive 2014/99/EC (European Commission - Fact Sheet, 2017). In particular, the European Commission notes that the Government of the Republic of Poland has not developed the relevant legal acts to determine the system for monitoring and checking gasoline regeneration systems. Commission Directive 2014/99/ EC is crucial for the protection of human health and the protection of the air by limiting the emission of volatile organic compounds of gasoline. Such emissions cause excessive levels of toxic benzene and photochemical ozone formation leading to respiratory diseases, including bronchial asthma. In addition, ozone is a greenhouse gas. Accordingly, in order to comply with the requirements of the European Commission's motivation decision, the Government of the Republic of Poland has a period of two months to resolve such a legislative gap. Failure to comply with the requirements of the European Commission is the basis for a lawsuit against the Republic of Poland to the Court of Justice of the European Union on the application of economic sanctions (European Commission - Fact Sheet, 2017). Also, the level of adverse impacts and harmful emissions in Romania, which results in more than 25,000 premature deaths per year, does not meet the air quality standards. The elimination of these disadvantages is possible by increasing the effectiveness of air monitoring by conducting an environmental assessment of air quality throughout the country and taking measures to limit the negative impact of pollutants (sulphur dioxide, nitrogen dioxide and nitrogen oxides, particulates, lead, benzene, carbon and ozone oxides, arsenic, cadmium, mercury, nickel and polycyclic aromatic hydrocarbons) on the population (European Commission - Fact Sheet, 2017).

Ensuring the quality of natural resources is a priority for leading foreign countries. In particular, according to UK legislation, the need for an environmental assessment before the design of any construction, and in the future - periodic monitoring of the environment has been determined. In the process of environmental planning and management, the initial version of the environmental expertise is compared with other assessment options, which allows more optimal determination of the parameters of anthropogenic impact (Rytikova, 2010).

Problems of household waste disposal, reduction of consumption of polyethylene bags in accordance with the requirements of EU Directive 2015/720 as of November 27, 2016. According to the EU Directive 2015/720 as of 
November 27, 2016, up to 2019, consumption is planned to be no more than 90 such packages per person per year, and by the end of 2025 - no more than 40 packages per person per year. The consumption of polyethylene bags should be reduced due to the introduction of prohibitions on their use. Certain requirements have been made to the governments of Cyprus, Greece, Italy, and Poland that they did not inform the European Commission of the measures taken. To comply with the European Commission's requirements, a deadline of two months is set, after the expiration of which sanctions in court will be imposed (European Commission - Fact Sheet, 2017).

The leading place in the utilization and recycling of the household waste in the countries of Western Europe is occupied by the Federal Republic of Germany. On a nationwide scale, the start of sorting waste was in 1990, when several large waste recycling enterprises were united under the brand Grüne Punkt ("Green Dot"). Since then, the responsibilities of every German include waste sorting. After all, unprocessed waste is a poison for nature and many types of waste can be used several times. Therefore, for example, for the return of specially marked bottles and beer cans, they return the deposit to the buyer (Diachuk, 2014).

Confirmation that the issue of environmental protection and ensuring the rational use of natural resources is the introduction of the practice of environmental actions in the developing country that does not have sufficient funds for the formation of appropriate funds, a country whose state budget allows such expenses. Between such countries, the so-called "debt-for-nature swaps" are concluded (Zimmermann, 1993). Their essence is that the bank or an interested group of environmentalists buys (or receives forever) from the creditor at a much lower price the part of the external debt of a developing country, which is unable to pay this debt. Then, this amount is transferred to the Central Bank of the borrower and used for environmental protection measures in a country that has been released from the debt. Debt write-off in exchange for measures to protect the environment is practiced by Germany (Martynenko).

\section{Conclusions}

The conducted analysis of the norms of legislation on the use of natural resources in foreign countries made it possible to conclude on the need to revise the taxation system of the relevant legal relations in Ukraine. Consequently, most countries apply economic mechanisms to regulate the use of natural resources.

Therefore, it is advisable to conclude that it would be expedient to increase the effectiveness of the interaction between Ukraine and the European Union in the implementation of intergovernmental environmental policy in order to preserve the environment in this part of the planet.

Studying the experience of legal regulation and organization of the system of public administration in the field of the use of natural resources in the countries of the European Union, United States of America, Great Britain, Canada, and other foreign countries allows us to conclude that it is expedient to implement it in Ukraine. Public management in the sphere of natural resource use in foreign countries is characterized by an extensive system of taxation of activities related to the use of natural resources, while there is a tendency to introduce direct taxes paid directly by natural resource users and indirect taxes (paid by other subjects). Also, the system of compulsory state fees for the use of natural resources includes payments for obtaining appropriate special permits (licenses) that are granted not only for the use of natural resources but also for activities related to environmental pollution. Thus, since the 1970s, the market of "rights" to pollution has been formed in the United States of America and, accordingly, through the implementation of such permits, special environmental funds are created and also financing of the system of state executive authorities and local self-government in the sphere of natural resources use is provided.

In addition, it is advisable to introduce an approach of the financial feasibility of national and regional programs in the field of natural resources utilization that are being implemented at the expense of state and local budgets.

\section{References:}

Mandzyk, V. M. Svitovyi dosvid spravliannia platezhiv za korystuvannia vodnymy resursamy [World experience in charging for the use of water resources]. Retrieved from: http://economics-of-nature.net/uploads/arhiv/2008/ Mandzyk.pdf

Malikova, O.I. (2001). Upravlenie ohranoj okruzhayushej sredyvFederativnoj respublike Germanii [Environmental management in the Federal Republic of Germany]. Vestnik Moskovskogo universiteta. Ekonomika, 1(6), 71-82. (in Russian)

Martynenko, V. O. Dosvid krain YeS shchodo suchasnykh mekhanizmiv upravlinnia okhoronoiu navkolyshnoho seredovyshcha $\mathrm{v}$ Ukraini [Experience of EU countries in modern mechanisms of environmental protection management in Ukraine]. Retrieved from: http://dspace.uabs.edu.ua/bitstream/123456789/896/1/5.pdf

Khvesyk, M. A., Holian, V. A. (2007). Instytutsionalna model pryrodokorystuvannia v umovakh hlobalnykh vyklykiv: monohrafiia [The institutional model of nature management in the context of global challenges: monograph]. Kyiv: Kondor. (in Ukrainian)

European Commission (2016). European Commission and Germany reach agreement on a fair and nondiscriminatory road charging scheme / European Commission. Press release, Brussels, 1 December 2016. Retrieved from: http://europa.eu/rapid/press-release_IP-16-4221_en.htm 
Environmental statistics in Europe (2010). Facts and figures on the environment: from environmental taxes to water resources. Environmental statistics in Europe, 189. Retrieved from: http://europa.eu/rapid/pressReleasesAction. do? reference $=$ STAT $/ 10 / 189 \&$ format $=$ HTML

European Commission - Fact Sheet (2017). June infringements package: key decisions. European Commission - Fact Sheet, Brussels, 14 June 2017. Retrieved from: http://europa.eu/rapid/press-release_MEMO-17-1577_en.htm

Rytikova, K. A. (2010). Teoretychni ta praktychni aspekty suchasnoho svitovoho dosvidu finansuvannia ekolohichnoi diialnosti [Theoretical and practical aspects of the modern world experience in financing environmental activities]. Teoretychni i praktychni aspekty ekonomiky ta intelektualnoi vlasnosti : zbirnyk naukovykh prats PDTU, vol. 2, pp. 230-235. (in Ukrainian)

Diachuk,O.V.(2014).Zyevropeiskoho dosviduzakhystu dovkillia. [From theEuropean experience of environmental protection]. Ekolohichnyi artykul. Retrieved from: http://www.library.vn.ua/elbooks/Ekologia2013/5.htm

Zimmermann, H. (Hrsg.) (1993). Umweltabgaben: Grundsatzfragen und abfalwirtschfftliche Anwendung. Bonn, S. 1. 